\title{
Analytical Chemistry Methods of Estimating the Original Firing Temperature of Bricks from a 19th Century Convent in the Philippines: Perspective of a Southeast Asian Country
}

\section{Mga Pamamaraan ng Mapanuring-Kimika sa Pagtantya ng Orihinal na Temperatura ng Pagsunog sa Ladrilyo Mula sa Isang Ika-19 na Siglong Kumbento sa Pilipinas: Pananaw ng Isang Bansa sa Timog-Silangang Asya}

Jan-Michael C. Cayme

Chemistry Department, De La Salle University, Manila, Philippines

jm.cayme@gmail.com

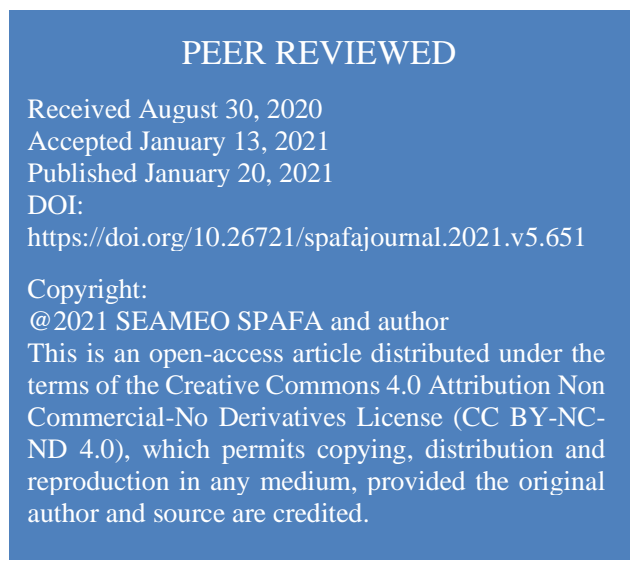

\begin{abstract}
Countries in Southeast Asia have a unique and diverse culture due to its varied ethnic groups having different traditions and beliefs. The process of manufacturing building materials such as brick masonry is one aspect where this distinctiveness is manifested. This study provides a general analytical chemistry method that will estimate the original firing temperature of a historical brick material from a convent in Milaor, Camarines Sur, Philippines. Different instrumental techniques were utilized namely the Energy Dispersive X-ray Fluorescence (EDXRF), Fourier Transform Infrared (FTIR) Spectroscopy and Scanning Electron Microscopy with Energy Dispersive X-ray (SEM-EDX). From these techniques, the chemical and mineralogical composition of the brick was reported. The clay mixture used in the production of the brick is known to be non-calcareous and low refractory, that was fired in an oxidizing atmosphere. The brick's microstructure is classified within the initial vitrification stage based on the features of the mineral transformations. The results of this study point to an estimated firing temperature range of $650^{\circ} \mathrm{C}$ to $850^{\circ} \mathrm{C}$. An emphasis on the importance of chemical analysis in studying cultural heritage materials in the Southeast Asian region is also highlighted on this paper.
\end{abstract}

Ang mga bansa sa Timog-Silangang Asya ay may natatangi at magkakaibang kultura sanhi ng iba't ibang mga pangkat etniko na may magkakaibang tradisyon at paniniwala. Ang pamamaraan ng paggawa sa mga materyales ng lumang gusali tulad ng ladrilyo ay isang aspeto kung saan naipapamalas ang pagkakaiba-iba nito. Ang pagaaral na ito ay nagbibigay ng isang pangkalahatang pamamaraan ng mapanuring-kimika para tantyahin ang orihinal na temperatura ng paggawa sa lumang ladrilyo mula sa isang kumbento ng Milaor, Camarines Sur, Pilipinas. Iba't ibang mga instrumento ang ginamit tulad ng Energy Dispersive X-ray Fluorescence (EDXRF), Fourier 
Transform Infrared (FTIR) Spectroscopy at ang Scanning Electron Microscopy na nakakabit sa Energy Dispersive $X$-ray (SEM-EDX). Mula sa mga intrumentong ito, ang kemikal at mineral na komposisyon ng ladrilyo ay iniulat. Ang mga pinaghalong luad na ginamit sa paggawa ng ladrilyo ay masaasabing hindi gaanong madami ang bilang ng kalsiyo at mababang refractory, na sinunog sa isang kapaligiran na sagana sa hangin. Ang mga pinaka-maliliit na istruktura ng ladrilyo ay masasabing nasa paunang yugto ng pagtunaw ng mga mineral sa luad, batay sa mga pagbabagong anyo ng mga ito. Sa mga resulta ng pagaaral, masasabi na ang tantyang temperatura ng pagsunog ay nasa $650^{\circ} \mathrm{C}$ hanggang $850^{\circ} \mathrm{C}$. Binibigyan ng diin ang kahalagahan ng pagsusuri ng kimika sa pagaaral ng mga materyales na pamanang kultura sa rehiyon ng Timog-Silangang Asya ay naitala din sa pagaaral na ito.

Keywords: clay mineral, iron oxide, quartz, EDXRF, FTIR, SEM-EDX, archaeology | luwad na mineral, iron oxide, quartz, EDXRF, FTIR, SEM-EDX, arkeolohiya

\section{Introduction}

Chemistry has provided significant contributions in understanding the provenance, manufacturing process and material composition of cultural heritage materials. Scientific diagnosis on the state of preservation and degradation of artifacts has led to the development of effective methodologies on the proper conservation and restoration in recent years. Studies on the application of analytical techniques in chemistry to different cultural and archaeological materials are increasingly being reported in literature (Schreiner et al. 2007; Madariaga 2015; Dey et al. 2020). These heritage materials include paintings, metal objects, potteries, textiles and masonry materials such as bricks and mortars to mention a few (Bitossi et al. 2005; Sarmiento et al. 2011; Oztoprak et al. 2016). Instrumentation techniques have also been rapidly progressing in becoming more portable, sensitive and sampling methods described as minimal to non-invasive (Melo et al. 2018). These are very important considerations for studying cultural heritage materials where sample amounts are critical, and others are not easily transported to the laboratory for chemical analysis. Depending on the research problem that needs to be understood, various instruments have been developed that would enable the researcher to literally "see" what is inside the sample (i.e., elemental and mineralogical composition) and how these different microscopic components interact with each other affecting the material as a whole (Madariaga 2015). From these information, a thorough knowledge on the heritage material can be acquired, that may not be readily obvious from historical documents. Southeast Asian countries can greatly benefit on these analytical chemistry techniques and should be a standard protocol in any cultural heritage research.

\section{Chemical Analysis of Bricks in the Southeast Asian Region}

In Southeast Asian countries, firing clays to form bricks has been practiced since ancient times. Brick masonry is also a widespread building material used for constructing sacred places, royal palaces, administrative buildings and fortifications in these regions (Miksic 2017). The Philippines brick-making history is believed to have largely started during the Spanish Colonial Period in the late $16^{\text {th }}$ century and there are no records of any pre-colonial temples in the country (Jose 2003). In comparison to other countries in Southeast Asia, brick-made religious temples dating to as early as the $6^{\text {th }}$ to $7^{\text {th }}$ centuries such as the Mỹ Són temples in Vietnam (Binda et al. 2009) and the Bujang Valley Archaeological sites in Malaysia (Zuliskandar Ramli et al. 2011; Zuliskandar Ramli et al. 2012), are relatively common in the region. 
Bricks are generally manufactured from clay and sand. The nature of clays is very important and will dictate the properties of the final brick material. Not all clays are the same and would depend on the geographical location where it was obtained (Jose 2003). Though some of the general elemental and mineralogical components maybe similar, its distribution in terms of the amount will be different in each clay. It is also important to emphasize that clays are composed of a plastic and a non-plastic component. Plasticity is the ability of clays to be easily moulded in water and will eventually harden when left to dry. Chemically, these plastic components are composed of aluminosilicates (i.e., clay minerals) in varied combinations and responsible for the plasticity behavior observed in clays. The non-plastic components are typical soil which is mainly silicates and are found naturally in clay (Holtz and Kovacs 1981). Different types of clays can be mixed depending on the brick making culture and the judgement of the brick maker, and sand (silicates) are added as tempers to make the final brick sturdier. After forming to the desired shape and dried, the moulded clay will be fired at a high temperature in a covered pit or inside a kiln until the desired physical property was achieved (Henderson 2000). Since all these activities would have involved personal estimations especially with regards to the exact firing temperature and the uniformity of the firing environment, chemical analysis is essential to expound on these processes.

There are limited studies related to the application of analytical chemistry techniques in understanding the production of historical bricks in the Southeast Asian region. From these studies, the analytical instruments frequently mentioned in literature are the X-ray techniques such as the Xray Fluorescence (XRF) and X-ray Diffraction (XRD), and the microscopy techniques, specifically the Scanning Electron Microscopy with Energy Dispersive X-ray (SEM-EDX), respectively. XRF determines the elemental composition while XRD provides the mineral phases of the brick sample. A specific type of XRF is the Energy Dispersive X-ray Florescence (EDXRF) which is more sensitive compared to an ordinary XRF. Functioning like a microscope but uses electrons instead of light, the SEM can visualize the surface structure of the brick sample with a magnification of greater than 100,000x in the nanometer level. It is usually coupled to an EDX which gives the elemental composition of the visualized image from the SEM, thus SEM-EDX. These instruments are generally available in most academic universities and research institutions in the region.

Chemical analysis was reported for bricks obtained from the Bujang Valley archaeological sites in Malaysia (Zuliskandar Ramli et al. 2011; Zuliskandar Ramli et al. 2012; Zuliskandar Ramli et al. 2013a, 2013b, 2013c, 2013d, 2013e; Zulikandar Ramli et al. 2014a, 2014b; Ratnah Wati Mohd Rapi et al. 2020) and the Batujaya archaeological site in Indonesia (Ali et al. 2014; Ali et al. 2015) showing that local clays were utilized for its production. Restoration efforts have also gained valuable insights from analytical techniques. Data from these instruments guided the restoration of brick temples damaged by an earthquake in Bagan, Myanmar (Thet Mon San et al. 2018) and the restoration works in Bangkok and Ayutthaya in Thailand (Mahasuwanchai et al. 2020). Information on how ancient brick was manufactured was reported in another study on the Bagan temples in Myanmar (Oh et al. 2019) and a Cham Dynasty temple in Vietnam (Abdrakhimov and Abdrakhimova 2018). Furthermore, research in Cambodia employ analytical techniques to study the sequence of brick construction based on the changes in chemical composition from temples at Sambor Prei Kuk (Shimoda et al. 2019) and Koh Ker (Uchida and Sakurai 2018). In Thailand, archaeological dating techniques such as thermoluminescence and optically stimulated luminescence were applied to bricks from archaeological sites at Wiang Kaen (Won-in et al. 2008), Thung Tuk (Pailoplee et al. 2010; Pailoplee et al. 2016) and the brick wall at Songkhla (Puttagan et al. 2019). Chemical and mineralogical characterization have been reported for ancient brick kilns in Sawankhalok, Thailand (Hein et al. 2004), Mỹ Són temple complex in Vietnam (Binda et al. 2009) and in the Philippines, bricks from Ilocos Norte and Pagsanjan, Laguna (Cayme and Asor Jr 2015; 
Cayme et al. 2016). These studies affirm the increasing importance of analytical chemistry techniques applied to brick masonry and the potential impact of Southeast Asians to this discourse. This paper contributes to this growing number of results from the region.

For this study, the focus is on the brick sample's estimated firing temperature and the conditions of the kiln during this process. Changes in the chemical and mineralogical structure of clay provides an indication of the original temperature when it was formed (Viani et al. 2018). An attempt to determine the firing temperature was made by researchers from Malaysia and Myanmar by monitoring the absence or presence of certain type of minerals (i.e., kaolinite and mullite) using XRD (Oh et al. 2019; Zuliskandar Ramli et al. 2012; Zuliskandar Ramli et al. 2013a, 2013c, 2013d, 2013e; Zuliskandar Ramli et al. 2014a). A different approach was performed in this study by combining different analytical techniques, specifically the EDXRF, SEM-EDX and the Fourier Transform Infrared (FTIR) spectroscopy techniques. The FTIR is another analytical instrument that gives information on the possible mineral changes that occurred during firing. The methodology of interpreting the data in this study were derived from research on ancient clay potteries (Dey et al. 2020). This is acceptable since both materials originated from clay in general albeit different clay types and firing temperature. Given similar conditions, the changes in the chemical and mineralogical components are likely the same. The importance of this study is in providing information on the skills and abilities of Filipino brick makers in the $19^{\text {th }}$ century, as well as the kiln technology used in the brick's manufacture. Furthermore, the results can serve as a baseline data on producing custom-made replacement bricks that has good compatibility with existing materials during conservation work.

\section{The Milaor Convent and the Brick Sample}

The Franciscan Religious Order (Order of Friars Minor) established the town of Milaor in 1585 as part of their network of missionary efforts in the Kabikolan region, which is the southern portion of the main island of Luzon in the Philippines (Totanes 2006). Presently, Milaor is one of the municipalities in the province of Camarines Sur (Figure 1). The church structure was originally built of wood and eventually reconstructed using brick materials from 1725 to 1735 . A wooden convent was also built during this time frame. The whole town was gutted by fire in 1740 including the church and convent. Series of reconstructions took place including a bell tower connected by a bridge to the church structure in 1840. The current brick convent was believed to be part of the 1884 construction (Figure 2) (De Huerta 1887). 

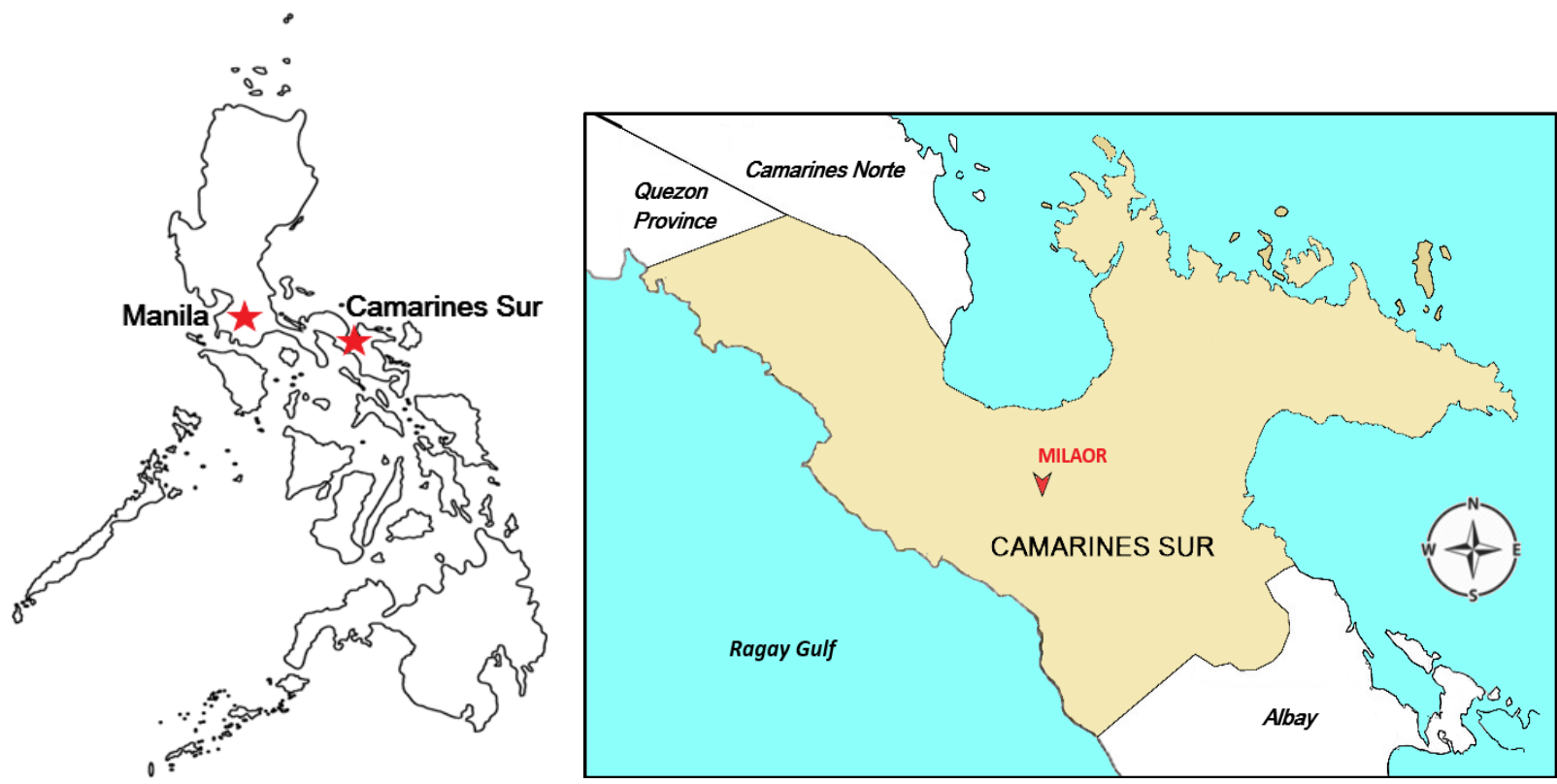

Fig. 1 Map of the Philippines showing the proximity of the Province of Camarines Sur relative to the country's capital, Manila (left). Map of the Province of Camarines Sur where the Municipality of Milaor is approximately located (right). Source: JM Cayme.

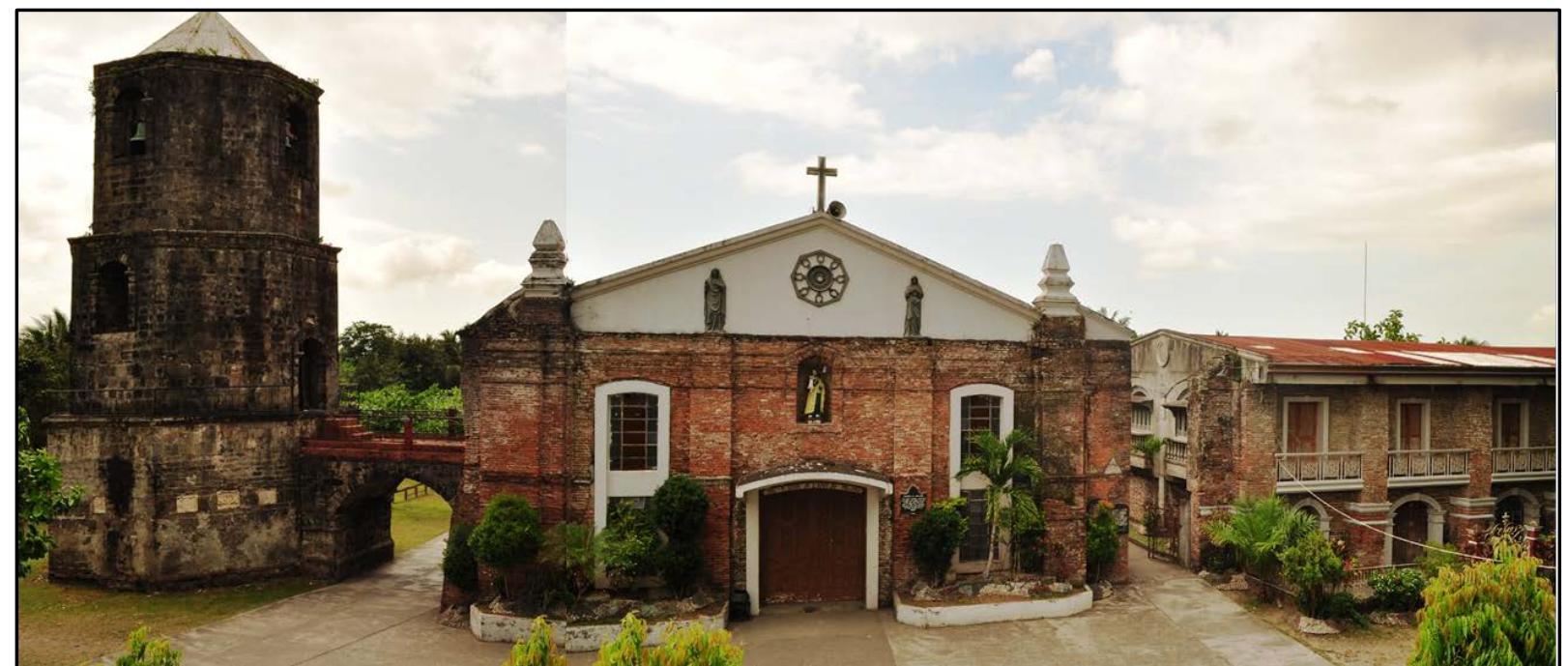

Fig. 2 The Parish of Milaor, Camarines Sur showing the bell tower (extreme left), the main church structure (middle) and the convent (extreme right). The brick sample used in this study was acquired from the convent. Source: Photo by JM Cayme, April 2014.

The brick sample used for chemical analysis in this study was obtained from the rear exterior wall of the convent in 2014 (Figure 2). It was detached from a discreet location approximately 2.5 feet from the structure's ground level. To prevent any contaminations from the surrounding materials, approximately $1-2 \mathrm{~cm}$ of the outer surface was gently removed, and the inner section was subjected to a combined EDXRF, FTIR and SEM-EDX analysis. Based on the physical characteristics of the brick, such as the size, texture and color (reddish-brown), it is likely that it was manufactured during the $19^{\text {th }}$ century.

\section{Experimental Analytical Methods}

The elemental composition of the brick sample was identified utilizing the Shimadzu EDX-7000 Energy Dispersive X-ray Fluorescence (EDXRF) Spectrometer. No sample pre-treatment was 
required before the analysis. Hence, the sample preparation is relatively straightforward. A small piece was simply placed on a polypropylene cup holder and the collimator was adjusted to $3 \mathrm{~mm}$. The instrument was set on a detailed analysis mode (about 5 minutes run time) in a vacuum atmosphere. All the volatile compounds are reported as the loss on ignition (LOI).

A Thermo Scientific Nicolet 6700 Fourier Transform Infrared (FTIR) Spectrometer was employed for qualitative mineral analysis and identifies the changes in the mineral content during the brick's firing process. The sample was prepared by grinding and mixing together with potassium bromide $(\mathrm{KBr})$ powder in an approximate ratio of 1-part sample to 3-parts $\mathrm{KBr}$. This powdered mixture was turned into a pellet (i.e., $\mathrm{KBr}$ pellet) which is a technique to fasten the sample onto the FTIR instrument holder. The pellet containing the sample was scanned repeatedly for $16 \mathrm{x}$ within the midinfrared region $\left(4000 \mathrm{~cm}^{-1}\right.$ to $500 \mathrm{~cm}^{-1}$ ) in transmission mode at a $4 \mathrm{~cm}^{-1}$ resolution (Cayme et al. 2016).

To directly visualize the microstructure changes of the brick sample at its original firing temperature a SEM/EDX JEOL JSM-5310 Scanning Electron Microscope coupled with Energy Dispersive X-ray (SEM-EDX) analyzer was employed. A small cross section representing the brick sample was attached to the SEM holder and held in place by a double sided conductive adhesive tape. After which, it was coated with a thin layer of gold (JEOL JFC-1200 Fine Coater) to make the sample more conductive and electrons will be produced upon the bombardment of X-ray beams. These beams will eventually be monitored by the instrument's detector to produce the image. The SEM image was analyzed using an Oxford Link Isis produced in a spot-profile and back-scattered electrons (BSE) mode. A magnification of 3,500x was taken for each analysis at an accelerating voltage of $25 \mathrm{kV}$. The EDX elemental profile was achieved at a resolution of $62 \mathrm{eV}$.

\section{Results and Discussion}

\section{Quantitative chemical composition}

Knowing the elemental composition will provide a general information on the provenance and possible manufacturing process such as the firing conditions of the brick material. The amount of fluxes which is important in determining the firing temperature was also accounted by the EDXRF. Furthermore, the clay type and the identity of its plastic and non-plastic components, were identified. As shown in Figure 3, silicates or silicon dioxide $\left(\mathrm{SiO}_{2}\right)$ is the most abundant element in the brick sample at $47.401 \%$ which is due to a sand and clay raw material origin. Sand is largely made up of quartz minerals or in chemistry, represented by repeating structural units of $\mathrm{SiO}_{2}$. On the other hand, clay mainly have both the non-plastic components (i.e., sand and feldspars) and the plastic components (phyllosilicates). It is the phyllosilicate minerals that is responsible in imparting the unique properties of clays. Since all these minerals mentioned contain silicon-oxygen (Si-O) chemical bonds, the amount of $\mathrm{SiO}_{2}$ naturally predominates in the EDXRF data.

Aluminate or aluminum oxide $\left(\mathrm{Al}_{2} \mathrm{O}_{3}\right)$ is also part of the chemical structure of feldspars and phyllosilicates (clay minerals). The combination of aluminum and silicon oxides form the different clay mineral layers and its ratio dictates the nature of the different clay types (Dey et al. 2020). It follows from the EDXRF data in Figure 3 that Al2O3 (19.276\%) is the next most abundant element type in the brick sample after silicon. Besides the silicon and aluminum, the major elements common in feldspars is the calcium and potassium which is evident from the calcium oxide $(\mathrm{CaO})$ and potassium oxide $\left(\mathrm{K}_{2} \mathrm{O}\right)$ content of the brick. These elements form part of the endmembers of 
typical feldspar termed as Ca-feldspar and K-feldspar. Calcium can also signify the presence of natural carbonated minerals such as calcium carbonate $\left(\mathrm{CaCO}_{3}\right)$ in the clay. Moreover, the potassium can also indicate illite clay mineral (Daghmehchi et al. 2018). The $\mathrm{SiO}_{2} / \mathrm{Al}_{2} \mathrm{O}_{3}$ ratio of 2.46 obtained for the sample are within the range for illite (2.7).

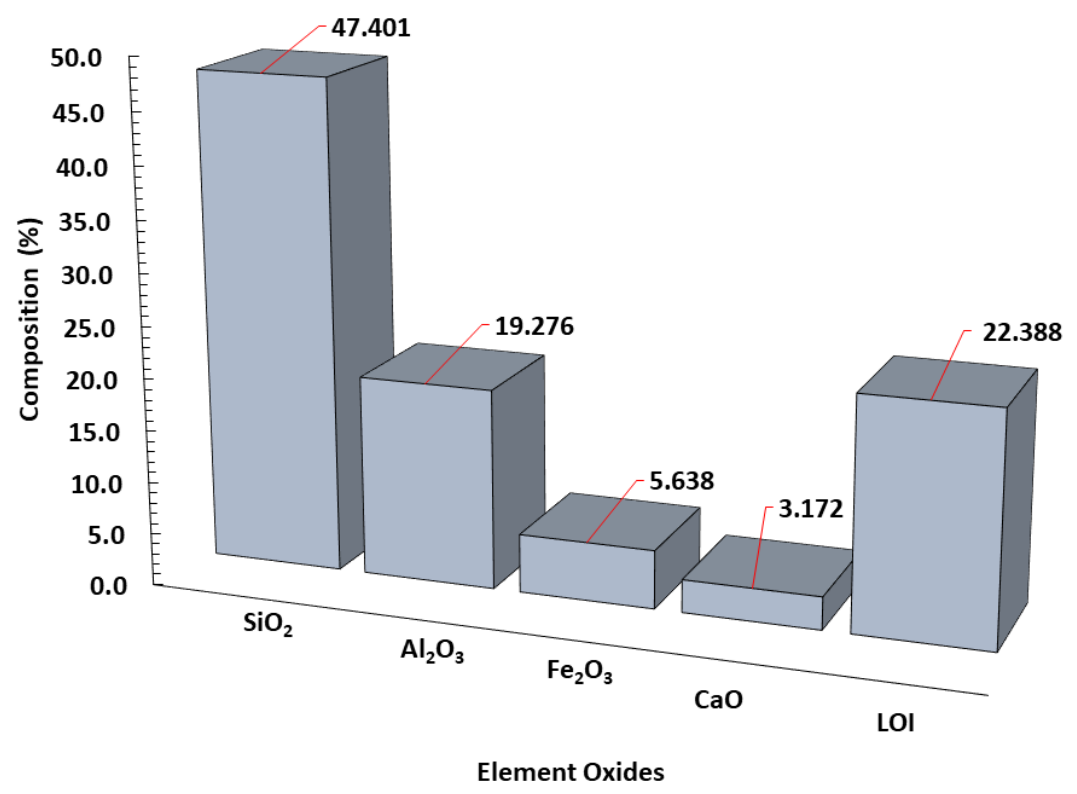

Fig. 3 Results of the EDXRF elemental data of the brick sample with composition greater than $1.00 \%$. The chemical element name attached to the oxygen forming the oxides are the following: Silicon (Si), Aluminum (Al), Iron (Fe) and Calcium (Ca). Loss On Ignition (LOI) are chemical compounds that are volatile.

The percentage of $\mathrm{CaO}$ (3.172\%) as shown in Figure 3 is indicative of a clay material that is noncalcareous. According to Musthafa et al. (2010), a CaO percentage of less than $6.0 \%$ is considered a non-calcareous clay, while a percentage greater than $6.0 \%$ is of the calcareous type. These classifications influence the firing minerals that will be formed in the clay as the temperature increases. Hence, affecting the formation of pores, bloating and vitrification process of the brick (Dey et al. 2020).

The total amount of fluxes is another important parameter that influence the temperature of vitrification. This is defined as the temperature where the fluxes will liquify and acts like a sealant, binding the surrounding minerals in the brick. These fluxes are the total amount of potassium oxide $\left(\mathrm{K}_{2} \mathrm{O}\right)$, iron oxide $\left(\mathrm{Fe}_{2} \mathrm{O}_{3}\right)$, calcium oxide $(\mathrm{CaO})$, magnesium oxide $(\mathrm{MgO})$ and titanium oxide $\left(\mathrm{TiO}_{2}\right)$ in the EDXRF data (Figures 3 and 4 ) which resulted to a value of $10.049 \%$. Note that magnesium oxide was not detected by the EDXRF and will be considered as negligible having an assigned amount of zero percent. Since the total value is greater than $9.0 \%$, this shows that the clay is a low refractory type (Maniatis and Tite 1981). The greater the amount of fluxes the more minerals are available for vitrification, therefore the process will be achieved at a lowered firing temperature. 


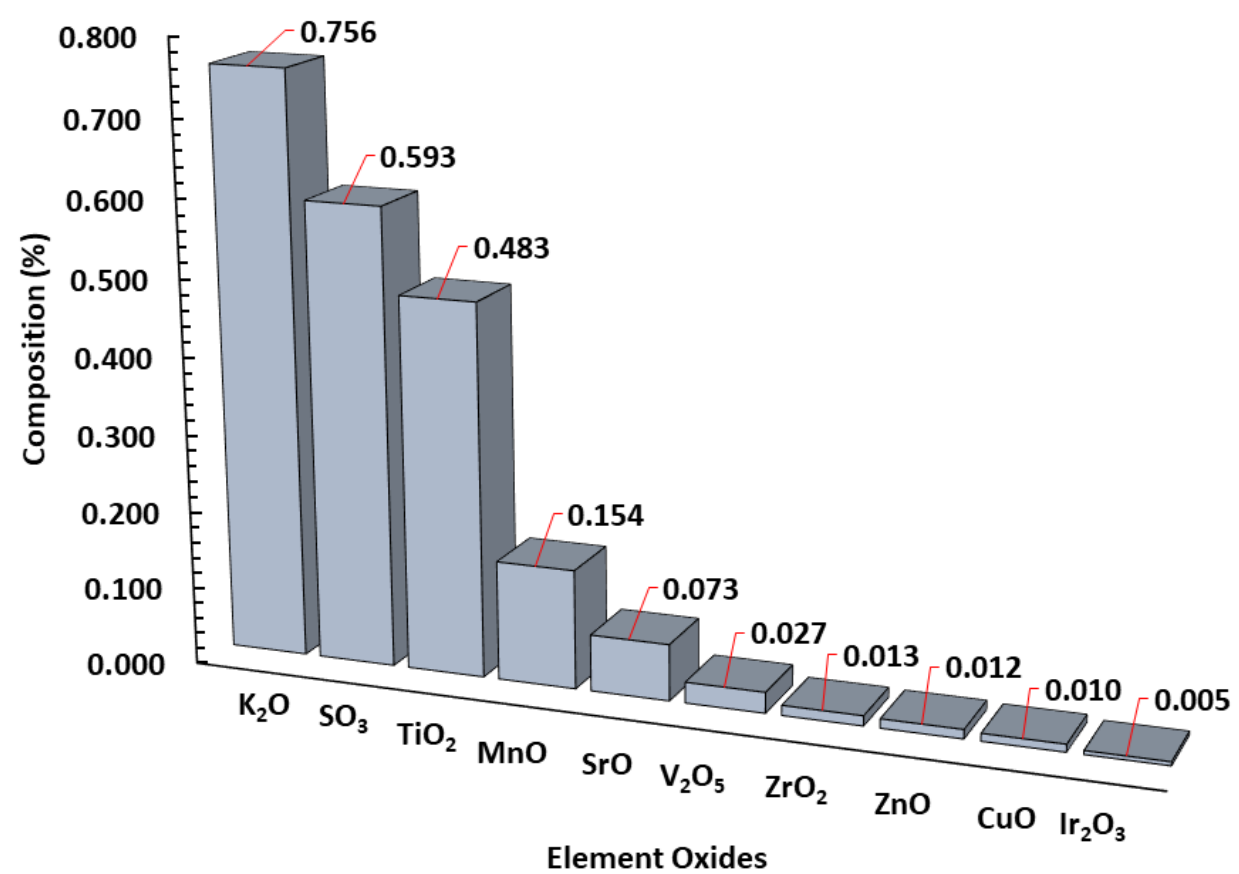

Fig. 4 Results of the EDXRF elemental data of the brick sample with composition less than 1.00\%. The chemical element name bonded to oxygen forming the oxides are the following: Potassium (K), Sulfur (S), Titanium (Ti), Manganese (Mn), Strontium (Sr), Vanadium (V), Zirconium (Zr), Zinc (Zn), copper (Cu) and Iridium (Ir).

Minerals containing iron oxides $\left(\mathrm{Fe}_{2} \mathrm{O}_{3}\right)$ are typically formed during firing and denotes the presence of hematite and magnetite. These two minerals coexist together in the brick material and its amount is dependent on the availability of oxygen from the surroundings during the firing process. This firing environment is described in literature as oxidizing (more oxygen) or reducing (less oxygen). Since the color of the brick is reddish brown, it is assumed that the firing was done in an oxidizing environment and favors the formation of more hematite compared to magnetite (Daghmehchi et al. 2018).

\section{Qualitative mineralogical composition}

The absorption peaks observed in the FTIR spectrum supports the results of the EDXRF data and validates the sand and clay origin of the brick sample. The most prominent feature in the FTIR spectrum in Figure 5 is the broad peak centered at $1099 \mathrm{~cm}^{-1}$ corresponding to the Si-O asymmetric stretching (v3) of quartz. Other significant peaks for the Si-O bond of quartz are the symmetric stretching (v1) at $796 \mathrm{~cm}^{-1}$ and the symmetric bending (v2) at $690 \mathrm{~cm}^{-1}$, respectively (Saikia et al. 2008). The terms symmetric, asymmetric, bending and stretching are descriptions used in chemistry to define the movement of the chemical bonds in the molecules. This movement is detected by the FTIR and recorded in the instrument as absorption peaks.

The original clay raw material should have distinct absorption peaks at $1100 \mathrm{~cm}^{-1}$ and $915 \mathrm{~cm}^{-1}$. When the temperature is increased, the minerals in the original clay break down (i.e., dehydroxylation) and eventually rearranges to another mineral form. Hence, these two peaks are no longer observed in the FTIR spectrum, instead one broad peak at $1099 \mathrm{~cm}^{-1}$ (Si-O peak) is formed. This will occur at a temperature of $650^{\circ} \mathrm{C}$ (Venkatachalapathy et al. 2002). Another possible indicator of a temperature limit is the formation of iron containing oxides in the FTIR spectrum. Magnetite and hematite are attributed to the peaks at $586 \mathrm{~cm}^{-1}$ and $542 \mathrm{~cm}^{-1}$, respectively, 
confirming the results of the EDXRF for the presence of these minerals. For these minerals to form in the brick sample, the temperature of firing should be higher than $600^{\circ} \mathrm{C}$ (Velraj et al. 2009). Thus, based on the Si-O and iron oxide peaks mentioned, it can be inferred that the lowest possible temperature limit should be at least $650^{\circ} \mathrm{C}$.

Clays are naturally mixed with sand which is mainly silicates $\left(\mathrm{SiO}_{2}\right)$ and clay minerals (phyllosilicates) with a ratio depending on the clay type. Tempers such as sand are usually added together with clay, hence increasing the amount of $\mathrm{SiO}_{2}$. This is the reason the EDXRF data was able to detect an abundant concentration of $\mathrm{SiO}_{2}$. It is expected that clay minerals would have overlapping FTIR peaks with the silicates and it would be difficult to distinguish its exact identity. The phyllosilicates or clay minerals also have hydroxide groups (O-H groups) in its structure and may overlap with the absorbed water $\left(\mathrm{H}_{2} \mathrm{O}\right.$ or $\left.\mathrm{H}-\mathrm{O}-\mathrm{H}\right)$ from the surroundings. This is assigned to the FTIR peaks at $3419 \mathrm{~cm}^{-1}$ and $1628 \mathrm{~cm}^{-1}$ (Cayme et al. 2016).

The possible higher temperature limit of the brick's firing process was determined by the presence of the weak FTIR peaks at $1382 \mathrm{~cm}^{-1}$ (Figure 5). This is assigned to the C-O asymmetric stretching (v3) of carbonates $\left(\mathrm{CO}_{3}{ }^{2-}\right)$ and specifically a calcite mineral or made of calcium carbonate $\left(\mathrm{CaCO}_{3}\right)$ (Cayme and Asor Jr 2016; Cayme and Asor Jr 2017). Carbonates usually evaporate to form carbon dioxide $\left(\mathrm{CO}_{2}\right)$ gas at a temperature of $850^{\circ} \mathrm{C}$. Since some carbonates are assumed to be present in the brick sample albeit at a small amount due to the FTIR peak's intensity, this implies that the upper firing temperature should not exceed $850^{\circ} \mathrm{C}$ (Yanik et al. 2012). Based on the overall FTIR results, the brick sample is likely fired between a temperature of $650^{\circ} \mathrm{C}$ to $850^{\circ} \mathrm{C}$.

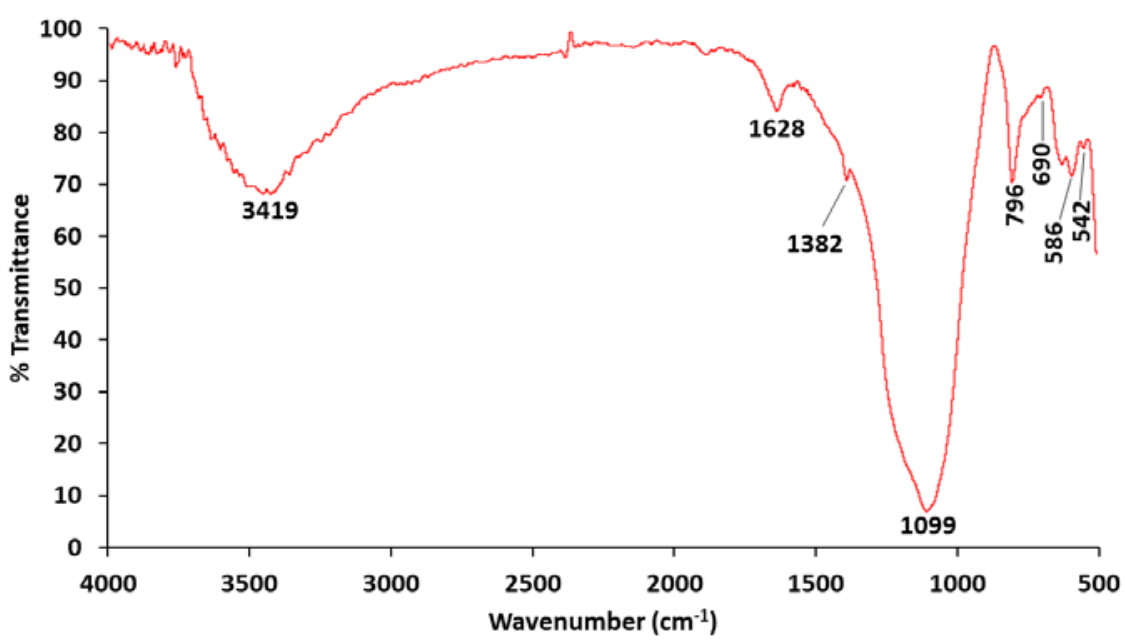

Fig. 5 FTIR spectrum of the brick sample in the mid-infrared region $\left(4,000 \mathrm{~cm}^{-1}\right.$ to $\left.500 \mathrm{~cm}^{-1}\right)$.

\section{Microstructure}

The cross-section SEM-EDX analysis of the brick shows the microstructural changes that happened to the sample during the original firing process. Based on how the particles look like, an estimated temperature can be attributed to the changes that took place. Two different positions were magnified 3,500 times through the SEM, the outer section and the middle section of the representative sample. This was done to see the consistency of the distribution of the elements and the microstructure changes within the sample. As shown in Figure 6a and b, the morphology of the brick indicates the melting of phyllosilicate clay minerals (labelled as 2; deformed irregular shape) have already started to bind or coat the silicate minerals (labelled as 1; more regular shape) together 
(Johari et al. 2010). This coating is also aided by the amount of fluxes (i.e. potassium, iron, calcium, magnesium and titanium) which is consistently identified from the EDX data (Figures 7 and 8) for both SEM images of the sample.
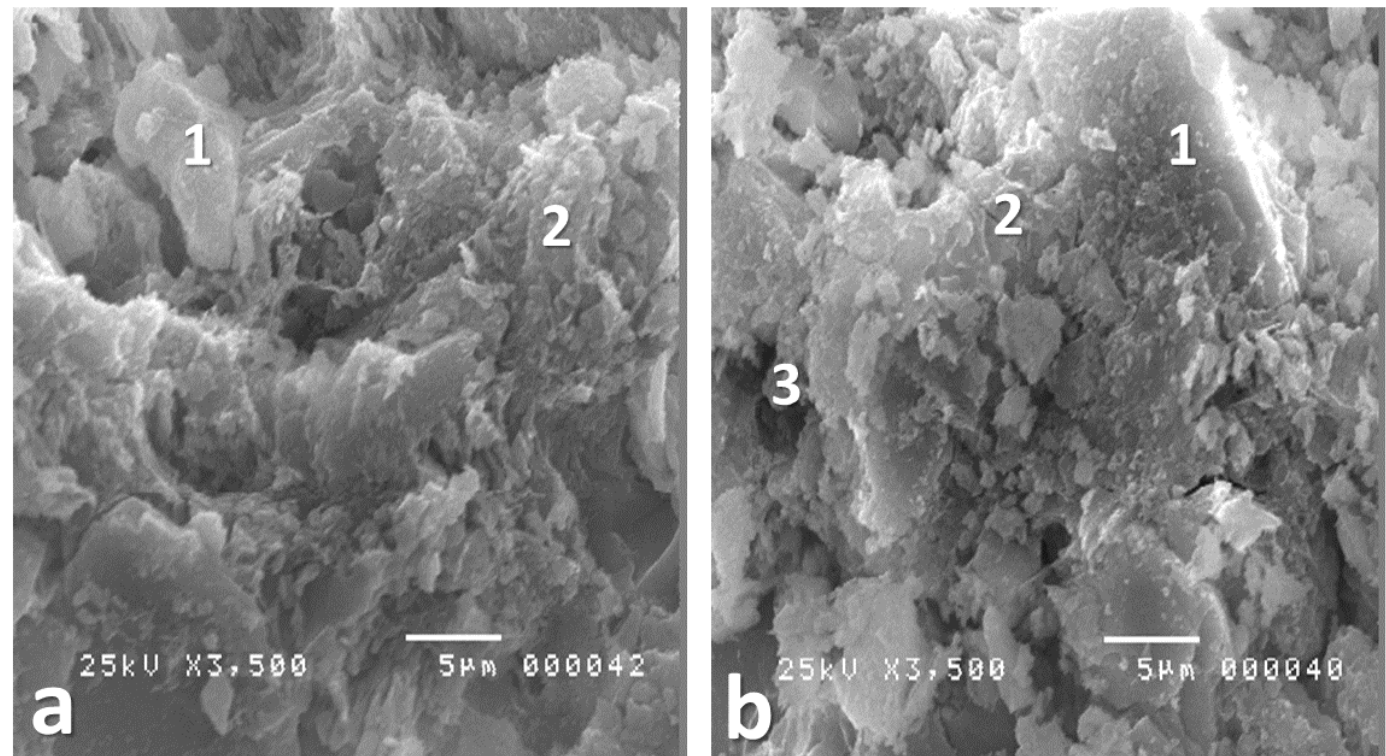

Fig. 6 SEM image of the brick sample at a magnification of x3,500 of the (a) middle section, and the (b) outer section.

Silicates $\left(\mathrm{SiO}_{2}\right)$ or quartz was clearly identified from the SEM image and supported by the elemental data (silicon) from the EDX in Figure 7. Quartz will vitrify or melt at a temperature greater than $1,000^{\circ} \mathrm{C}$. Since, quartz can still be observed, this confirms that the brick sample was fired lower than this temperature. The formation of iron oxides is also evident from the EDX, confirming the results of the FTIR that a firing temperature greater than $600^{\circ} \mathrm{C}$ was achieved for these minerals to form. The presence of carbonates likely in the form of calcite $\left(\mathrm{CaCO}_{3}\right)$ may have caused some isolated pores $(2.0$ to $3.0 \mu \mathrm{m})$ to form within the structure, an example of which, is labelled as 3 in Figure 6. Pores of these sizes are usually observed for bricks fired in an oxidizing atmosphere at a relatively lower temperature. This shows that carbonates are slowly being liberated from the brick structure and as predicted by FTIR, will start at around $850^{\circ} \mathrm{C}$. Based on the comparison of the EDX data (Figures 7 and 8) for the outer and middle sections, the distribution of elements are quite consistent within the brick's microstructure. This suggests that the brick sample was equally fired at the designated temperature.

The average $\mathrm{Si} / \mathrm{Al}$ ratio from EDX measurement obtained for the middle and outer section is 1.78 which matches that of montmorillonite clay. The basic structural unit of illite, identified through the EDXRF, is identical to montmorillonite. Both consists of an alumina or gibbsite sheet sandwich between two silica sheets in a 2:1 ratio (Holtz and Kovacs 1981). In the case of illite, the individual structural units are bonded with each and non-exchangeable potassium ions are present in-between. This prevents water from entering the structure, hence classified as a non-expanding clay. On the other hand, the interlayer space of montmorillonite is occupied by exchangeable water molecules and a temperature of $650^{\circ} \mathrm{C}$ to $800^{\circ} \mathrm{C}$ is ideal to remove the water (Figure 9). This suggests that during the firing process, montmorillonite may have been converted to illite which explains the 
relative abundance of potassium in both the EDXRF and EDX data. Coexistence of montmorillonite and illite in historical brick materials need to be supported further with large number of samples.

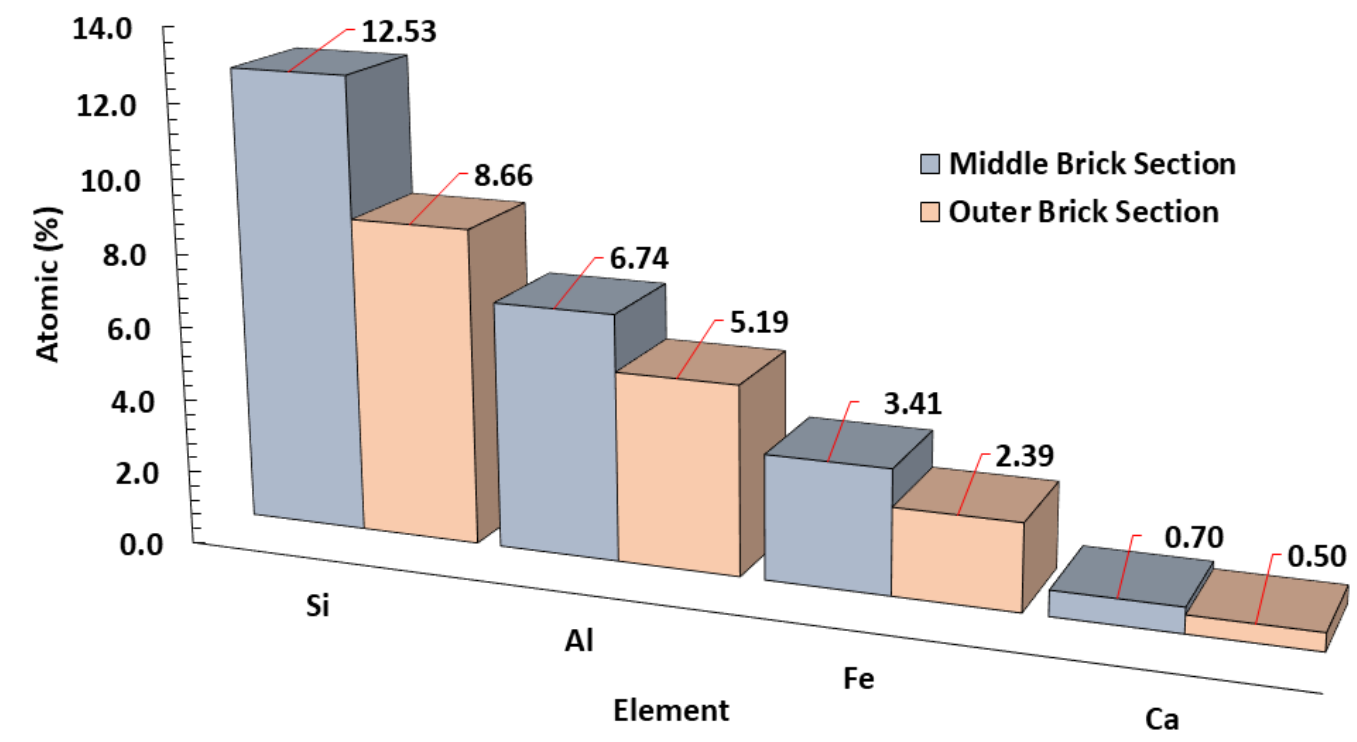

Fig. 7 Comparison of the EDX data corresponding to the SEM images in Figure 6. The graph represents the atomic percentages greater than or equal to $0.50 \%$. The chemical elements have the following names: Silicon ( $\mathrm{Si}$ ), Aluminum (Al), Iron (Fe) and Calcium (Ca).

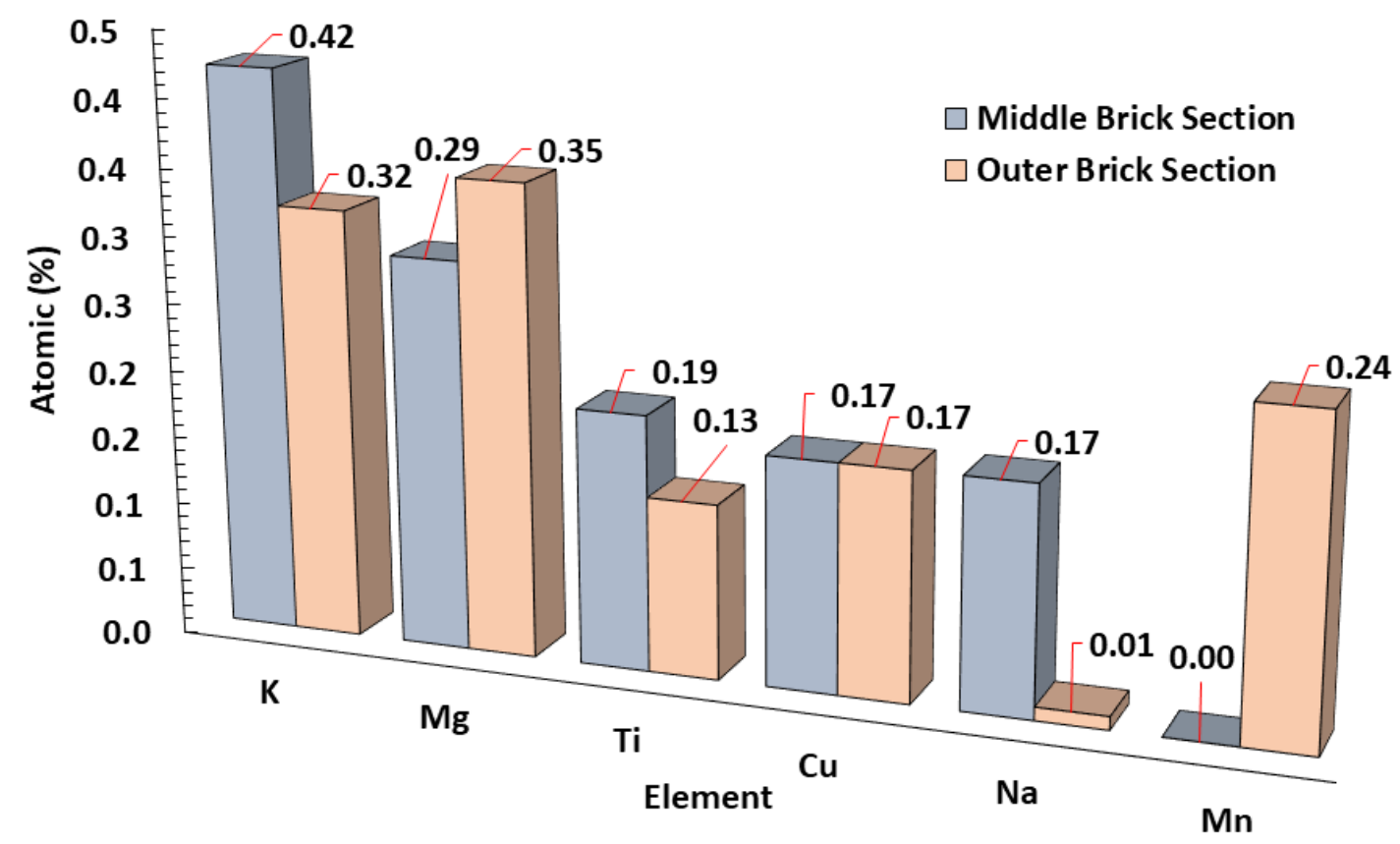

Fig. 8 Comparison of the EDX data corresponding to the SEM images in Figure 6. The graph represents the atomic percentages less than $0.50 \%$. The chemical elements have the following names: Potassium (K), Magnesium (Mg), Titanium (Ti), Copper (Cu), Sodium (Na) and Manganese (Mn). 

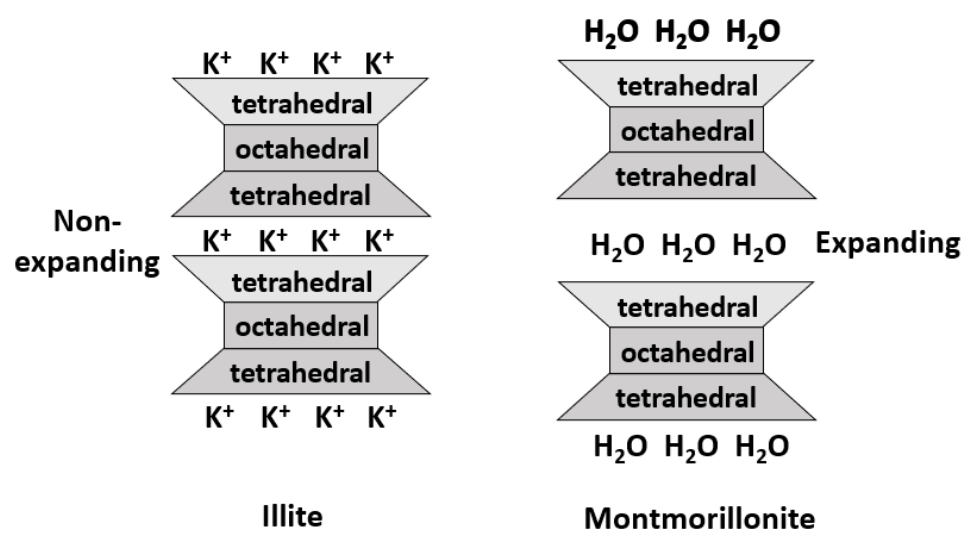

Fig. 9 Schematic representation of an illite and montmorillonite showing a non-expanding and expanding clay type.

There was no large-scale vitrification or the appearance of a dominant glass phase in both SEM images. The term glass phase would look like a flowing liquid appearance, which was not observed in the sample. However, slight distortions of the phyllosilicate clay minerals (labelled as 2 in Figure $6 a$ and $b$ ) that appears to have a formation of a slight smooth surface was identified. Based on the classifications in the literature, these kinds of observations are assigned within the initial vitrification (IV) stage (Chatfield 2010; Bland et al. 2017). Together with the results of the EDXRF and FTIR which identified the clay raw material as non-calcareous and low refractory, a maximum temperature between $800-850^{\circ} \mathrm{C}$ is designated for the brick sample (Maniatis and Tite 1981).

\section{Conclusion}

Analytical chemistry techniques have been proven to be a very useful tool in deepening the understanding of cultural heritage materials particularly the brick's firing temperature. The results of this study have extended the understanding of colonial period building materials in the Philippines and provided baseline information for possible conservation work in the future. It was demonstrated that the brick material was originally fired at an oxidizing atmosphere or plenty of oxygen with a temperature range from $650^{\circ} \mathrm{C}$ to $850^{\circ} \mathrm{C}$. Further study of other bricks in the region will allow a better understanding of the brick manufacturing culture developed within Southeast Asia.

\section{Acknowledgement}

The author expresses his sincere gratitude to Fr. Muriel T. Abiog, parish priest of the Saint Joseph the Worker Parish, Diocese of Libmanan, Milaor, Camarines Sur for giving permission and supervising the collection of brick samples used in this study. The expertise of Mr. Sean Mikhail Dalawampu of Shimadzu Philippines for his assistance in operating the EDXRF and the Shimadzu Philippines Corporation for providing the instrument, are greatly appreciated. The generous support of the Chemistry Department of the De La Salle University, Manila, is highly recognized. This study would not have been possible without the helpful insights and assistance of the following persons from the De La Salle University, Manila: Dr. Glenn Alea, Dr. Jaime Raul Janairo, Mr. Michael Ajero, Mr. Aniano Asor Jr. and Mr. Reynaldo Coria (SEM-EDX data). 


\section{References}

Abdrakhimov, VZ and Abdrakhimova, ES (2018) Chemical-Elemental, Phase Compositions and Porosity Structure of Ceramic Samples from Cham Tower (Vietnam) More Than 1000 Y/O. Glass Ceramics 75, 154-159.

Ali, MSM, Ramli, Z and Utomo, BB (2014) Compositional analysis of ancient bricks from the SegII temple (Unur Lempeng), Batujaya, Indonesia. In: D Efizon, JM Jahi, A Yusri, Windarti, Yoserizal, H Asriwandari, MR Razman, Z Ramli, M Seari and Ismanto (eds.) Proceeding of the $7^{\text {th }}$ International Seminar on Ecology, Human Habitat and Environmental Change in the Malay World. Pekanbaru, Riau, Indonesia, 199-207.

Ali, MSM, Ramli, Z, Rahman, NHSNA, Samian, AL, Razman, MR and Utomo, BB (2015) X-ray and x-ray diffraction analysis of ancient bricks from the temple SEG-II (Ubur Lempang), Batujaya, Indonesia. Journal of Food, Agriculture and Environment 13(2):197-200.

Binda, L, Condoleo, P and Tedeschi, C (2009) Materials Characterisation. In: A Hardy, M Cucarzi, and P Zolese (eds.) Champa and the Archaeology of Mỹ Són (Vietnam). Singapore: National University of Singapore (NUS) Press, 283-311.

Bitossi, G, Giorgi, R, Mauro, M, Salvadori, D and Dei, L (2005) Spectroscopic techniques in cultural heritage conservation: A survey. Applied Spectroscopy Reviews 40(3):187-228.

Bland, CA, Roberts, AL, Popelka-Filcoff, RS and Santoro, CM (2017) Early vitrification stages identified in prehistoric earthenware ceramics from northern Chile via SEM. Journal of Archaeological Science: Reports 16:309-315.

Cayme, JM and Asor Jr, A (2015) Extraction methods for quantifying iron, calcium and magnesium in a historic brickwork produced during the Spanish colonial period in the Philippines. Kimika 26(1):28-38.

Cayme, JM and Asor Jr, A (2016) Characterization of historical lime mortar from the Spanish colonial period in the Philippines. Conservation Science in Cultural Heritage 16:33-44.

Cayme, JM and Asor Jr, A (2017) Calcium content of lime mortars from $19^{\text {th }}$ century church ruins in the Philippines using volumetric analysis. Malaysian Journal of Analytical Science 21(5):1080-1090.

Cayme, JM, Asor Jr, A, Alano, MKA and Miranda, E (2016) Chemical characterization of historical brickwork of the church convent in Pagsanjan, Laguna. Kimika 27(1):30-41.

Chatfield, M (2010) Tracing firing technology through clay properties in Cuzco, Peru. Journal of Archaeological Science 37(4):727-736.

Daghmehchi, M, Rathossi, C, Omrani, H, Emami, M and Rahbor, M (2018) Mineralogical and thermal analysis of the Hellenistic ceramics from Laodicea Temple, Iran. Applied Clay Science 162:146-154.

De Huerta, F (1887). Estado geografico, topografico, estadistico, historico-religioso de la provincia apostolica de San Gregorio Magno. Manila, Binondo.

Dey, T, Carter, JC and Swift, K (2020) SEM-EDX and FTIR analysis of archaeological ceramic potteries from southern Italy. Microscopy 69(6):371-380.

Hein, D, Hill, G, Ross, W and Ramsay, H (2004) Raw or pre-fired: Kiln construction at Sawankhalok, North Central Thailand. International Journal of Historical Archaeology 8(4):247-266.

Henderson, J (2000) The Science and Archaeology of Materials: An Investigation of Inorganic Materials. London and New York: Routledge, Taylor \& Francis Group. 
Holtz, RD and Kovacs, WD (1981) An Introduction to Geotechnical Engineering. Upper Saddle River, NJ: Prentice-Hall.

Johari, I, Said, S, Hisham, B, Bakar, A and Ahmad, ZA (2010) Effect of the change of firing temperature on microstructure and physical properties of clay bricks from Beruas (Malaysia). Science of Sintering 42:245-254.

Jose RT (2003) Palitada: Skin of the Church. In: Skin Surface Essence. Manila: Ateneo Art Gallery, Ayala Foundation, Inc., Eugenio Lopez Foundation, Inc., and Museum Pambata Foundation, Inc., 13-29.

Madariaga, JM (2015) Analytical chemistry in the field of cultural heritage. Analytical Methods 7:4848-4876.

Mahasuwanchai, P, Wonganan, N, Athisakul, C, Tangchirapat, W, Sahamitmongkol, R and Leelataviwat, S (2020) Engineering properties of ancient masonry materials in Thailand and substitution materials for historical structures preservation. In: CW Tong, W Chin-Tsan, BSL Huat and X Xiang (eds.) International Conference on Sustainable Energy and Green Technology 2019. IOP Conf. Series: Earth and Environmental Science, 463:012077.

Maniatis, Y and Tite, MS (1981) Technological examination of Neolithic-Bronze age pottery from Central and Southeast Europe and from the Near East. Journal of Archaeological Science 8:59-76.

Melo, MJ, Nevin, A and Baglioni, P (2018) Special issue of Pure and Applied Chemistry devoted to “Chemistry and Cultural Heritage”. Pure and Applied Chemistry 90(3):429-433.

Miksic, JN (2017) The development of urban places in Southeast Asia. In: J Habu, P Lape and J Olsen (eds) Handbook of East and Southeast Asian Archaeology. Springer, New York, 547557.

Musthafa, AM, Janaki, K and Velraj, G (2010) Microscopy, porosimetry and chemical analysis to estimate the firing temperature if some archaeological pottery shreds from India. Microchemical Journal 95:311-314.

Oh, SJ, Kim, DM and Wi, KC (2019) The study on physical properties of red bricks of the Bagan remains in Myanmar. International Journal of Advance Sciences and Technology. 28(5):239-253.

Oztoprak, BG, Sinmaz, MA and Tülek, F (2016) Composition analysis of medieval ceramics by laser-induced breakdown spectroscopy (LIBS). Applied Physics A 122:557.

Pailoplee, S, Chaisuwan, B, Takashima, I, Won-In, K and Charusiri, P (2010) Dating ancient remains by thermoluminescence: Implications of incompletely burnt bricks. Bulletin of Earth Sciences of Thailand 3(1):8-16.

Pailoplee, S, Won-In, K, Chaisuwan, B and Charusiri, P (2016) Thermoluminescence and optically stimulated luminescence dating of bricks from the Thung Tuk archaeological site, Southern Thailand. Songklanakarin Journal of Science and Technology 38(6):699-705.

Puttagan, T, Chawchai, S, Surakiatchai, P, Chalorsantisakul, S and Preusser, F (2019) Luminescence dating of brick constructions being part of Songkhla City Wall, Southern Thailand. Archaeological and Anthropological Sciences 11:5393-5403.

Ratnah Wati Mohd Rapi, Ahmad Fadly Jusoh and Mokhtar Saidin (2020) Mineralogical and geochemical properties of bricks from Sungai Batu monuments. Bulletin of the Geological Society of Malaysia 69:149-156. 
Saikia, BJ, Parthasarathy, G and Sarmah, NC (2008) Fourier transform infrared spectroscopy estimation of crystallinity in $\mathrm{SiO}_{2}$ based rocks. Bulletin of Material Science 31(5):775-779.

Sarmiento, A, Pérez-Alonso, M, Olivares, M, Castro, K, Martínez-Arkarazo, I, Fernández, LA and Madariaga, JM (2011) Classification and identification of organic binding media in artworks by means of Fourier transform infrared spectroscopy and principal component analysis. Analytical and Bioanalytical Chemistry 399:3601-3611.

Schreiner, M, Melcher, M and Uhlir, K (2007) Scanning electron microscopy and energy dispersive analysis: applications in the field of cultural heritage. Analytical and Bioanalytical Chemistry 387:737-747.

Shimoda, I, Uchida, E and Tsuda, K (2019) Estimated construction order of the major shrines of Sambor Prei Kuk based on an analysis of bricks. Heritage 2:1941-1959.

Thet Mon San, Kyaw Kyaw and Nyan Myint Kyaw (2018) Physical, mechanical and chemical characterization on Ancient Brick Masonry of Monuments, Bagan, Myanmar. International Journal of Trend in Scientific Research and Development 3(1): 875-881.

Totanes, SHS (2006) From missions to mainstream: Franciscan efforts in Nueva Cáceres, Kabikolan, 1578-1768. In: DB Apilado (ed.) The Journal of History: Selected Papers on Cultural History and Ethnohistory. Manila: Philippine National Historical Society, Inc, 42:97-127.

Uchida, E and Sakurai, Y (2018) Construction sequence of the Koh Ker monuments constrained by the chemical composition and magnetic susceptibility of its bricks. Archaeological Discovery 6:173-185.

Velraj, G, Janaki, K, Musthafa, AM and Palanivel, R (2009) Spectroscopic and porosimetry studies to estimate the firing temperature of some archaeological pottery shreds from India. Applied Clay Science 43:303-307.

Venkatachalapathy, R, Sridharan, T, Dhanapandian, S and Manoharan, C (2002) Determination of firing temperature of ancient potteries by means of infrared and Mössbauer studies. Spectroscopy Letters 35(6):769-779.

Viani, A, Cultrone, G, Sotiriadis, K, Ševčík, R and Šašek, P (2018) The use of mineralogical indicators for the assessment of firing temperature in fired-clay bodies. Applied Clay Sciences. 163:108-118.

Won-in, K, Wattanadul, P, Dararutana, P, Pongkrapan, S, Takashima, I, Ruangrunsri, N and Vichapan, K (2008) Preliminary study of the age of the Lanna period by thermoluminescence dating: A case study from the Wiang Kaen Ancient Site, Chiang Rai, Northern Thailand. In: RI Kostov, B Gaydarska and M Gurova, M (eds) Geoarchaeology and Archaeomineralogy, Proceedings of the International Conference. Sofia: St. Ivan Rilski, 130-133.

Yanik, G, Bozer, R, Çeken, M, Esenli, F and Gocmez, H (2012) The characterization of medieval ceramics excavated from the Eğirdir Caravanserai (Turkey). Ceramics-Silikáty 56(3):261268.

Zuliskandar Ramli, Nik Hassan Shuhaimi Nik Abd. Rahman, Abdul Latif Samian, Suhaini Md. Noor and Mohd Ambar Yarmo (2011) Scientific analysis of ancient bricks at Bukit Pendiat Temple (Site 17) and Pengkalan Bujang Temple (Site 23): A comparative study. Research Journal of Applied Sciences 6:473-478. 
Zuliskandar Ramli, Nik Hassan Shuhaimi Nik Abd. Rahman, Adnan Jusoh and Mohd. Zobir Hussein (2012) Compositional analysis on ancient bricks from Candi Sungai Mas (Site 32/34), Bujang Valley, Kedah. American Journal of Applied Sciences 9(2):196-201.

Zuliskandar Ramli, Nik Hassan Shuhaimi Nik Abd. Rahman, Abdul Latif Samian and Mohd Ambar Yarmo (2013a) X-ray diffraction and x-ray fluorescence of ancient bricks of Candi Bukit Pendiat (Site 17), Bujang Valley, Kedah. Research Journal of Applied Sciences, Engineering and Technology 6(6): 1094-1100.

Zuliskandar Ramli, Nik Hassan Shuhaimi Nik Abdul Rahman, Abdul Latif Samian, Muhammad Rizal Razman, Sharifah Zarina Syed Zakaria and Ahmad Rizal Mohd Yusof (2013b) Scientific studies of Candi Pengkalan Bujang (Site 19) ancient bricks: Knowledge of old Kedah community's in usage of local raw materials. Research Journal of Applied Sciences, Engineering and Technology 6(15): 2859-2864.

Zuliskandar Ramli, Nik Hassan Shuhaimi Nik Abd. Rahman, Adnan Jusoh, Yunus Sauman and Muhammad Rizal Razman (2013c) X-ray diffraction and X-ray fluorescence of $\left(9^{\text {th }}-10^{\text {th }}\right.$ century AD) ancient bricks of Pengkalan Bujang Temple (Site 21/22) Bujang Valley, Kedah. The Social Sciences 8(6):500-504.

Zuliskandar Ramli and Nik Hassan Shuhaimi Nik Abdul Rahman (2013d) Compositional analysis of ancient bricks, Candi Bukit Kechil, Bujang Valley, Kedah. Research Journal of Applied Sciences, Engineering and Technology 6(5): 924-930.

Zuliskandar Ramli, Nik Hassan Shuhaimi Nik Abd. Rahman, Abdul Latif Samian, Adnan Jusoh, Yunus Sauman and Othman Mohd Yatim (2013e) Compositional analysis of ancient bricks at Site 2211, Candi Pengkalan Bujang, Kedah. Research Journal of Applied Sciences, Engineering and Technology 6(16):3027-3033.

Zuliskandar Ramli, Nik Hassan Shuhaimi Nik Abdul Rahman, Abdul Latif Samian, Muhammad Rizal Razman, Sharifah Zarina Syed Zakaria and Hossein Sarhaddi Dadian (2014a) X-ray diffraction (XRD) and x-ray fluorescence (XRF) analysis of ancient bricks from Sungai Batu Temple (site SB1), Bujang Valley, Kedah. Journal of Food, Agriculture \& Environment 12(3\&4): 360-364.

Zuliskandar Ramli, Nik Hassan Shuhaimi Nik Abdul Rahman, Abdul Latif Samian, Muhammad Rizal Razman, Sharifah Zarina Syed Zakaria and Ahmad Rizal Mohd Yusof (2014b) Usage of local raw material in the construction of Candi Pengkalan Bujang (Site 18), Bujang Valley, Kedah. Research Journal of Applied Sciences, Engineering and Technology 7(9):1779-1786. 